\title{
EFFECT OF MULCHING ON SOIL NUTRIENT LOSS REDUCTION, CASE STUDY OF WESTERN LANDS KHUZESTAN PROVINCE, IRAN
}

\author{
Mandana Shahnavaz ${ }^{1,3}$, Mehdi Nourzadeh Haddad ${ }^{2,}$, Ali Gholami $^{3}$ and Ebrahim Panahpoor ${ }^{3}$ \\ ${ }^{1}$ Department of Soil Science, Khouzestan Science and Research Branch, Islamic Azad University, Ahvaz, Iran \\ ${ }^{2}$ Department of Agriculture, Payame Noor University, Iran \\ ${ }^{3}$ Department of Soil Science, Ahvaz Branch, Islamic Azad University, Ahvaz, Iran
}

Received - September 22, 2016; Revision - November 28, 2016; Accepted - December 28, 2016

Available Online - December 29, 2016

DOI: http://dx.doi.org/10.18006/2016.4(VIS).730.741

KEYWORDS
Wind erosion
Polymer
Vegetable-based mulch
Soil loss
Nutrient loss

\begin{abstract}
One major negative effects of wind erosion is the loss of fertile soil which reduce the soil productivity. This study was conducted to evaluate the effect of wind erosion on the loss soil fertility and organic matter. Further, the effect of mulching on the reduction of soil erosion was also studied in present study. Study was conducted at the West Khuzestan province of Iran and soil loss situation was created by using simulator. Results of study revealed that average soil wind erosion was $26.73,24.58$ and $16.36 \mathrm{Kg} / \mathrm{m}^{2} / \mathrm{h}$ in Borvayeh, Alvan and Hoveyzeh, respectively. Significant difference was reported between the control (without use of any stabilizer) and samples treated with polymer. Average soil erosion is very high in soil without any stabilizer but the rate of erosion, compared to the control sample. The results of study showed that wind erosion causes loss of nitrogen in soil and it was reported maximum $\left(0.008 \mathrm{~kg} / \mathrm{m}^{2} / \mathrm{h}\right)$ in the soil of Hoveyzeh. Further maximum loss in phosphorus $\left(1.1 \mathrm{~kg} / \mathrm{m}^{2} / \mathrm{h}\right)$ and organic matter $(0.49$ $\mathrm{kg} / \mathrm{m}^{2} / \mathrm{h}$ ) was reported from the soil of Alvan. This nutrient loss may cause serious environmental and economic problems in the land exposed to long term erosion. The use of polymer and vegetable-based mulch with structural stability, on an average, reduced $99.5 \%$ loss soil elements (except in concentrations $15 \%$ vegetable-based mulch that reduced $13.2 \%$ loss of soil elements).Use of polymers enhanced the stability and connections aggregates in surface soil through the formation of the surface layer and resistant to corrosive force winds prevent the dust, soil loss and nutrient loss.
\end{abstract}

* Corresponding author

E-mail: m.nourzade@ gmail.com (Mehdi Nourzadeh Haddad)

Peer review under responsibility of Journal of Experimental Biology and Agricultural Sciences.

Production and Hosting by Horizon Publisher India [HPI] (http://www.horizonpublisherindia.in/).

All rights reserved.
All the article published by Journal of Experimental Biology and Agricultural Sciences is licensed under a Creative Commons Attribution-NonCommercial 4.0 International License Based on a work at www.jebas.org.

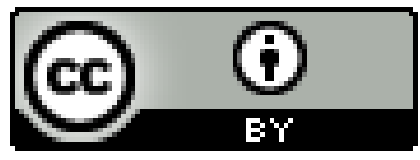




\section{Introduction}

Soil is one of the main natural resources but from past few decades, this valuable natural resource is continuously destroyed and devalued by wind erosion (KohneShahri \& Sadeghi, 2005). Under arid and semi-arid climatic condition, this is the one of the most important environmental problems (Behera et al., 2007). Further, it also destroy agricultural land, cause expansion in desert areas, buried channels, contaminate the surface water, loss of plant tissues and reduce photosynthesis ( National project management dust 2010). In recent years, this pollution of aerosols from dust storms as a result of wind erosion has become serious threatened for the health of citizens (Gravandi et al., 2016); recent studies suggested that $12 \%$ of cardiovascular and respiratory diseases in Kermanshah, Tabriz, Isfahan and Ahwaz, related to concentrations of more than $10-20 \mu \mathrm{g} / \mathrm{m}^{3}$ dust particles (Ghozikali et al., 2015; Gravandi et al., 2016; Zalaghi, 2010).

More than 1.25 million hectares of the total area of the Kozestan province are the desert and in this sense it is the most vulnerable regions in the country. Currently in the Kozestan province there are more than 280 thousand hectares of critical resources and dust. In addition, more than 380 thousand preference dust, are becoming critical areas for dust production (Nourzadehhadad \& Bahrami, 2016). With the spread of erosion in a region, topsoil is continuously removed. This effect is not seen often in real time but seriously, cause environmental and economic problems in the future and over time, to reduce the amount of soil nutrients, decreases soil productivity and rise need for fertilizers to maintain crop productivity (Bosede, 2010).

Anasiru et al. (2013) conducted a study in order to analyze the economic value of soil loss caused by soil erosion in Indonesia and reported that in studied four erosion units the rate of erosion is 406 tons per hectare per season and it causing the loss of $2648 \mathrm{~kg}$ of carbon per hectare per season, $230 \mathrm{~kg}$ of nitrogen per hectare per season, $30 \mathrm{~kg}$ phosphorus per hectare per season and $69 \mathrm{~kg}$ potash per hectare per season. Similar type of study was conducted by Li et al. (2007) in 2004 - 2006 at southern New Mexico land of America and reported that wind storms caused more than $25 \%$ loss in total organic carbon and nitrogen than $5 \mathrm{~cm}$ of soil. Colazo \& Buschiazzo (2015) studied textural changes induced by wind erosion in cultivated soils of different granulometry for asses textural changes produced by wind erosion in Argentinean.

Result of this study showed reduction in clay accumulation in aggregates of larger sizes produced by agriculture, which indicates an increase in the risk of removal of these particles by wind in loamy soils (Colazo \& Buschiazzo, 2015). By using ${ }^{137} \mathrm{c}_{\mathrm{s}}$ technique Li et al. (2014) studied the effect of soil redistribution on soil organic carbon (SOC) and total nitrogen (TN) stocks in an agricultural catchment of northeast china and reported net losses in SOC and $\mathrm{TN}$ over the past 56years and it was approximately 152 and 11 tons respectively. SOC and TN in the investigated catchment, erosion-induced SOC and TN losses per year are around $1.2 \times 10^{6}$ and $0.1 \times 10^{6}$ tons. Nourzadeh et al. (2013) studied the effects of soil moisture on the threshold friction velocity wind erosion, horizontal flux of sediment and dust concentration in Khuzestan province and reported that soil moisture increases the threshold friction velocity and has reduced sediment horizontal transport and dust concentrations.

Results of previous studies suggested that increasing the particle diameter at the soil surface and structural stability is the factors that can control surface abrasion and erosion. Application of polymer and soil stabilizer is considered as an agent of wind erosion control and soil conservation techniques in recent years. These polymers create a network on the soil surface that acted as a bridge between soil particles and by connecting the particles to each other and creating a more coarse aggregate soil which increases the aggregate stability (Abassi et al., 2010b). This study aimed to evaluate the effects of wind erosion on soil nutrient and soil organic matter loss in the land affected by wind erosion. Further, effect of polymer (polyvinyl acetate) and vegetable-based mulch (obtained from palm tree) on the reduction of soil nutrients loss was assessed by using open circuit simulators wind erosion, which was designed and built, in the area susceptible to wind erosion Khuzestan province.

\section{Materials and Methods}

In order to measure soil erosion, loss of nutrient and organic matter, soil samples were removed from the surface layer (up to $5 \mathrm{~cm} \mathrm{depth)}$ of Alvan, Hoveyzeh and Borvayeh. The location of sampling sites has been shown in Fig (1). Soils of these selected areas are dry and have high salinity, sandy texture and arid ricthermal regime with hyperthermic moisture regime.

Collected soil samples were taken in to the laboratory for further investigation. From these collected samples total nitrogen was estimated by Kjeldahl method (Bremner, 1982), phosphorus by Olsen method (Olsen \& Sommers, 1982), potassium by extraction methods with ammonium acetate (Thomas, 1982) and organic materials were analyzed by Walkley \& Black method (Walkley \& Black IA, 1934).

Measuring the intensity of wind erosion and factors influencing this under natural conditions is always difficult and expensive (Lopez, 1998). Using of wind erosion simulators is one of the alternative methods (Mahmoud Abadi et al., 2011) and it can be quickly and effectively measured the soil properties as well as transport mechanisms under controlled conditions (Burri et al., 2011). 


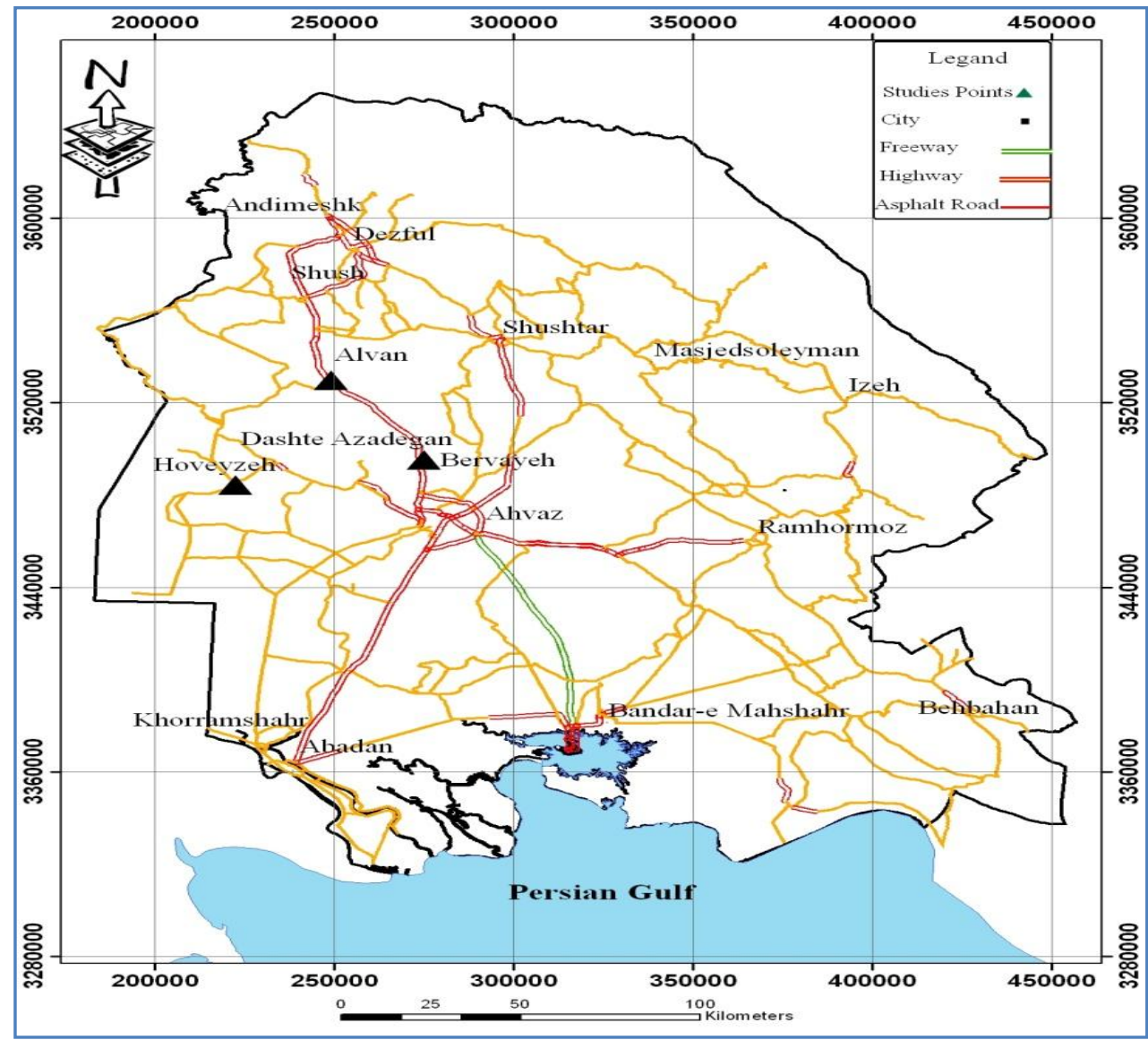

Figure1 location of sampling sites.

Wind erosion simulators for this study was designed and built with five main components viz. (i) Fan tube wind generator with $2800 \mathrm{rpm}$, (ii) metal casing, (iii) a glass window for viewing soil particle transport mechanisms, (iv) digital Wind velocity meter, (v) inverter device to adjust the fan speed wind generator. Overview of developed device has been given in figure (4). After filling the trays from air-dried soil, mulch to a concentration from zero (control), 15\%, 30\% and 60\% was sprayed on the soil surface so that cover the entire surface of the soil (Figure 2). The samples were placed in the natural

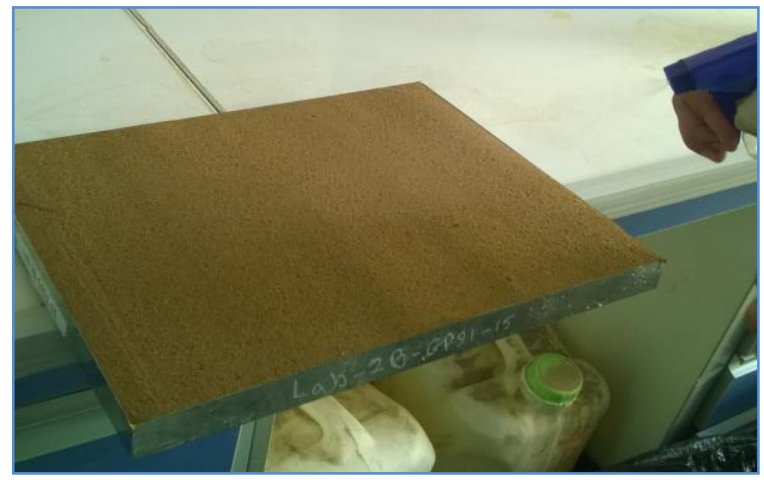

Figure 2 Mulching the soil sample. environment for 72 hours, to mulch sprayed completely dry. After carefully weighing, tray (Scales with an accuracy of one gram), were placed in the desired location in device (Figure 3). In order to evaluate treatments against severe wind erosion, the maximum speed was considered the central axis of the tunnel. Maximum Speed the in central axis of the tunnel (1.18 inches above the soil surface) reached to 13 meters per second (47 Kilometer per hour).That correspond with maximum wind speeds of Khuzestan and more than wind erosion threshold is sampled areas.

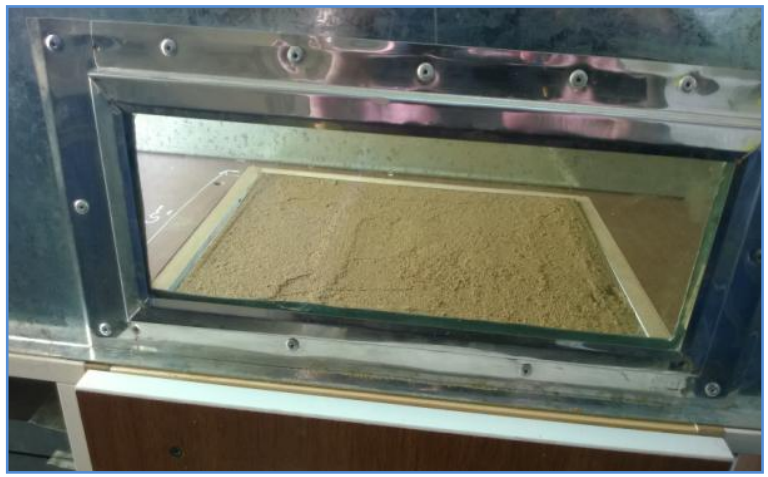

Figure 3 place the sample in the device. 


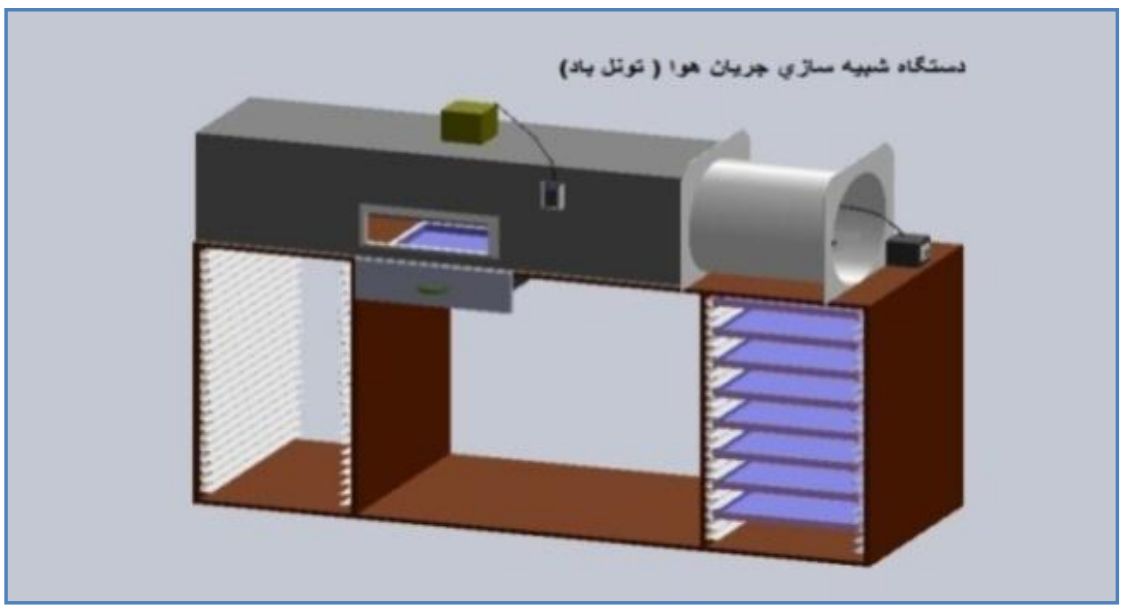

Figure 4 view of the open circuit simulators wind erosion.

The time for testing was considered 5 minutes. After completing the test, the samples are removed from the device and re-weighed. The difference in weight of samples at the beginning and end of the experiment was considered as the soil erosion.

In order to analyze the effect of polymer and vegetable-based mulch on the wind erosion, test results were analyzed in format of factorial experiment in a completely randomized design with 16 SPSS software.

\section{Results and Discussion}

Chemical properties of the studied areas soil samples, including texture, electrical conductivity and acidity have been indicated in Table 1 . The average soil loss were evaluated at the speed of 13 meters per second under two types ( polymer and vegetable-based mulch) in four levels of treatment 0 (control), $15 \%, 30 \%$ and $60 \%$ in simulators wind erosion devise in 5 minutes and the results of this these are presented in Table 2.
3.1 The effect of mulches on soil erosion

Result of study revealed that the use of polymer and vegetablebased mulch (as a stabilizer) create a stable layer on the soil surface, which reduced the soil loss due to wind erosion. In terms of impact of stabilizer on the reduction of soil loss statistically no significant difference was reported between used two stabilizers but these two are significantly different than the control (Table 3).

Results shown in Table 2, suggested that average soil erosion, without any stabilizer are $26.73 \mathrm{~kg} / \mathrm{m}^{2} / \mathrm{h}$ in Borvayeh sample, while it was reported $24.58 \mathrm{~kg} / \mathrm{m}^{2} / \mathrm{h}$ in Alvan and $16.36 \mathrm{~kg}$ $/ \mathrm{m}^{2} / \mathrm{h}$ in Hoveyzeh samples. Further, the rate of erosion in polymer treatments as compared to control decreased more than $99 \%$. Result of study suggested that at $60 \%$ concentration of polymer, erosion decreased $0.61 \mathrm{~kg} / \mathrm{m}^{2} / \mathrm{h}$ in the Borvayeh sample, while this value was $0.37 \mathrm{~kg} / \mathrm{m}^{2} / \mathrm{h}$ and $0.61 \mathrm{~kg} / \mathrm{m}^{2} / \mathrm{h}$ for Alvan and Hoveyzeh samples respectively.

Table 1 The Physicochemical properties of the Alvan, Hoveyzeh and Borvayeh are soils.

\begin{tabular}{|l|lccc|}
\hline S. N & Soil properties & \multicolumn{3}{c|}{ Sampling location } \\
\cline { 2 - 4 } & & Hoveyzeh & Alvan & Borvayeh \\
\hline 1 & Sand $(\%)$ & 72.5 & 90.6 & 94.5 \\
\hline 2 & Silt $(\%)$ & 15.5 & 3.4 & 1.5 \\
\hline 3 & Clay $(\%)$ & 12 & 6 & 4 \\
\hline 4 & Soil texture & sandyloam & sand & sand \\
\hline 5 & Bulk density $\left(\mathrm{gr} / \mathrm{cm}^{3}\right)$ & 1.8 & 1.85 & 7.85 \\
\hline 6 & PH & 7.09 & 7 & 7.1 \\
\hline 7 & Ec $(\mathrm{ms} / \mathrm{m})$ & 18.12 & 1.79 & 0.12 \\
\hline 8 & Organic Matter $(\%)$ & 0.2 & 0.2 & 0 \\
\hline 9 & N $(\%)$ & 0.005 & 0.005 & 0 \\
\hline 10 & Phosphorus $(\mathrm{ppm})$ & 0.1 & 4.53 & 0.1 \\
\hline 11 & Potassium $(\mathrm{ppm})$ & 125 & 156 & 143 \\
\hline
\end{tabular}


Table 2 Average soil erosion in the use of polymer and vegetable-based mulch in speed of $13 \mathrm{~m} / \mathrm{s}$ in wind erosion simulators for 5 minutes.

\begin{tabular}{|c|c|c|c|c|c|c|}
\hline \multirow[t]{2}{*}{ Row } & \multirow[t]{2}{*}{ Soil } & \multirow{2}{*}{$\begin{array}{l}\text { Concentration } \\
\text { of mulch }(\%)\end{array}$} & \multicolumn{2}{|c|}{ Polymer } & \multicolumn{2}{|c|}{ Vegetable-Based Mulch } \\
\hline & & & $\begin{array}{l}\text { Average erosion } \\
\text { during the test }(\mathrm{g})\end{array}$ & $\begin{array}{c}\text { Average erosion } \\
(\mathrm{kg} / \mathrm{m} 2)\end{array}$ & $\begin{array}{c}\text { Average erosion } \\
\text { during the test }\end{array}$ & $\begin{array}{c}\text { Average erosion } \\
(\mathrm{kg} / \mathrm{m} 2 / \mathrm{h})\end{array}$ \\
\hline 1 & & 0 & 219.2 & 26.73 & 219.2 & 26.73 \\
\hline 2 & Borvayeh & 15 & 10 & 1.22 & 190.65 & 23.25 \\
\hline 3 & & 30 & 8 & 0.98 & 72.8 & 8.87 \\
\hline 4 & & 60 & 5 & 0.61 & 17.97 & 2.19 \\
\hline 5 & Alvan & 0 & 201.6 & 24.58 & 201.6 & 24.58 \\
\hline 6 & & 15 & 8 & 0.98 & 8 & 0.98 \\
\hline 7 & & 30 & 5 & 0.61 & 4 & 0.49 \\
\hline 8 & & 60 & 3 & 0.37 & 5 & 0.61 \\
\hline 9 & & 0 & 134.6 & 16.36 & 134.3 & 16.36 \\
\hline 10 & Hoveyzeh & 15 & 15 & 1.83 & 6 & 0.73 \\
\hline 11 & & 30 & 5 & 0.61 & 9 & 1.1 \\
\hline 12 & & 60 & 5 & 0.61 & 3 & 0.37 \\
\hline
\end{tabular}

Results of statistical analysis that included two type of soil stabilizer (polymer and vegetable-based mulch), four levels $(0,15 \%, 30 \%$, $60 \%$ ), three soil types and three repeats have been shown in Table 3.

Table 3 Table analysis of variance effect of type mulch, concentration mulch and type soil on soil loss.

\begin{tabular}{|l|l|l|}
\hline Sources of changes & Degrees of freedom & Mean Square amount of soil loss \\
\hline Type mulch & 1 & ${ }^{\text {ns }} 3483920.056$ \\
\hline concentration mulch & 3 & ${ }^{* *} 4.369$ \\
\hline type soil & 2 & ${ }^{* *} 6908978.181$ \\
\hline error & 65 & 414087.329 \\
\hline total & 72 & \\
\hline
\end{tabular}

ns :There isnot a significant difference; $* *$ There is a significant difference at $1 \%$

According to Table 3, different concentrations of polymer are significant at $1 \%$. Comparison of the average erosion by Duncan method revealed that there is no significant difference between mean wind erosion of soil at $30 \%$ and $60 \%$ concentrations of polymer with $15 \%$ and $30 \%$ concentrations, but there are significant differences between $15 \%$ and $60 \%$ mulch concentrations to reduce.
The average soil loss by wind erosion in Borvayeh sample treated with vegetable-based mulch decreased to $2.19 \mathrm{~kg} / \mathrm{m}^{2} / \mathrm{h}$ at 60 concentration while this value was reported $23.25 \mathrm{~kg} / \mathrm{m}^{2} / \mathrm{h}$ in case of $15 \%$ concentration. Similarly in case of polymer treatment, soil loss in wind erosion decreased to $0.61 \mathrm{~kg} / \mathrm{m}^{2} / \mathrm{h}$ at 60 percent concentration while this was reported 1.22 $\mathrm{kg} / \mathrm{m}^{2} / \mathrm{h}$ at 15 percent concentration.

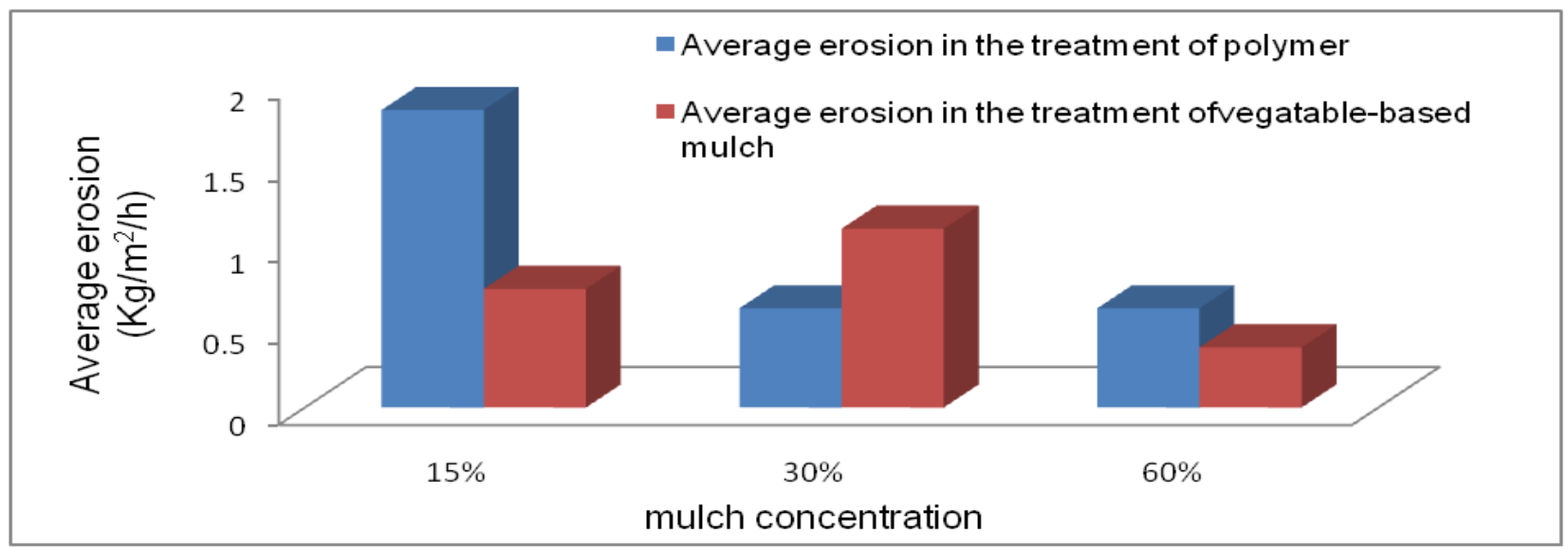

Figure 5 Average soil erosion in Hoveyzeh samples treated with polymer and vegetable-based mulch. 


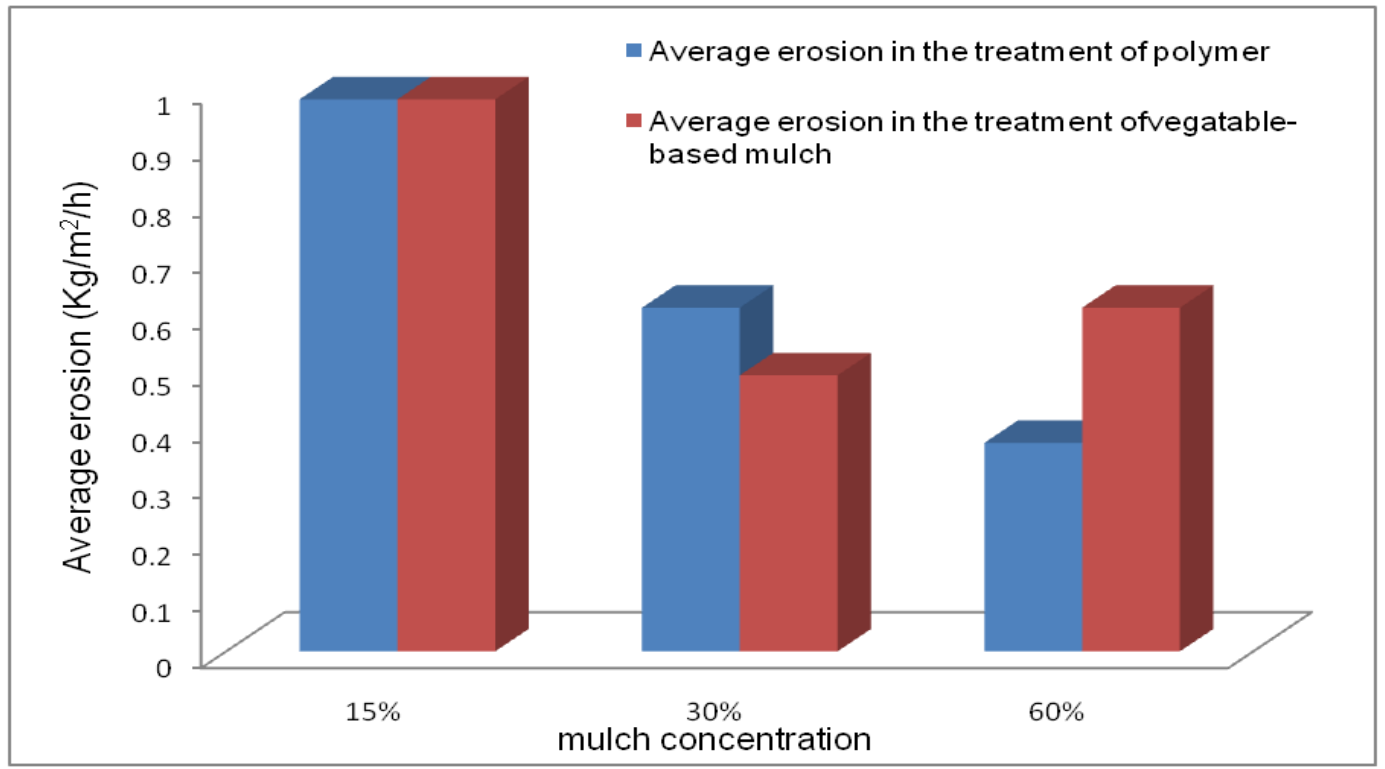

Figure 6 Average soil erosion in Alvan samples treated with polymer and vegetable-based mulch.

These results are in agreement with the findings of Han et al. (2007) those who reported the influence of polymers on the reduction of soil erosion. These researchers evaluated soil erosion at 25.3 meters per second and reported $0-0.4 \mathrm{~kg} / \mathrm{m}^{2} / \mathrm{h}$ erosion (Han et al., 2007). Further, the average soil erosion in the Borvayeh control soil was $26.73 \mathrm{~kg} / \mathrm{m}^{2} / \mathrm{h}$. The test results showed soil loss in 15, 30 and 60 percent concentrations of vegetable-based mulch was $23.22 \mathrm{~kg} / \mathrm{m}^{2} / \mathrm{h}(13 \%$ reduction in erosion), $8.87 \mathrm{~kg} / \mathrm{m}^{2} / \mathrm{h}(66.8 \%$ reduction in erosion) and 2.19 $\mathrm{kg} / \mathrm{m}^{2} / \mathrm{h}(91.8 \%$ reduction in erosion) respectively, while soil loss in Borvayeh samples at treatments with polymer in 15, 30 and 60 percent concentrations was $1.22 \mathrm{~kg} / \mathrm{m}^{2} / \mathrm{h}(99.5 \%$ reduction in erosion), $0.98 \mathrm{~kg} / \mathrm{m}^{2} / \mathrm{h} 98 / 0$ (99.63\% reduction in erosion), and $0.61 \mathrm{~kg} / \mathrm{m}^{2} / \mathrm{h} 61 / 0$ (99.77\% reduction in erosion) respectively. Khan (2014) investigated the effect of mulch (F2SR-231) on stabilizing the sand dunes and reported mulch resistance against winds (90 kilometers per hour), was confirmed in the wind tunnel. In deserts, positive effect of these polymers in reducing soil erosion and protecting plants and soils were reported by Khan (2014).

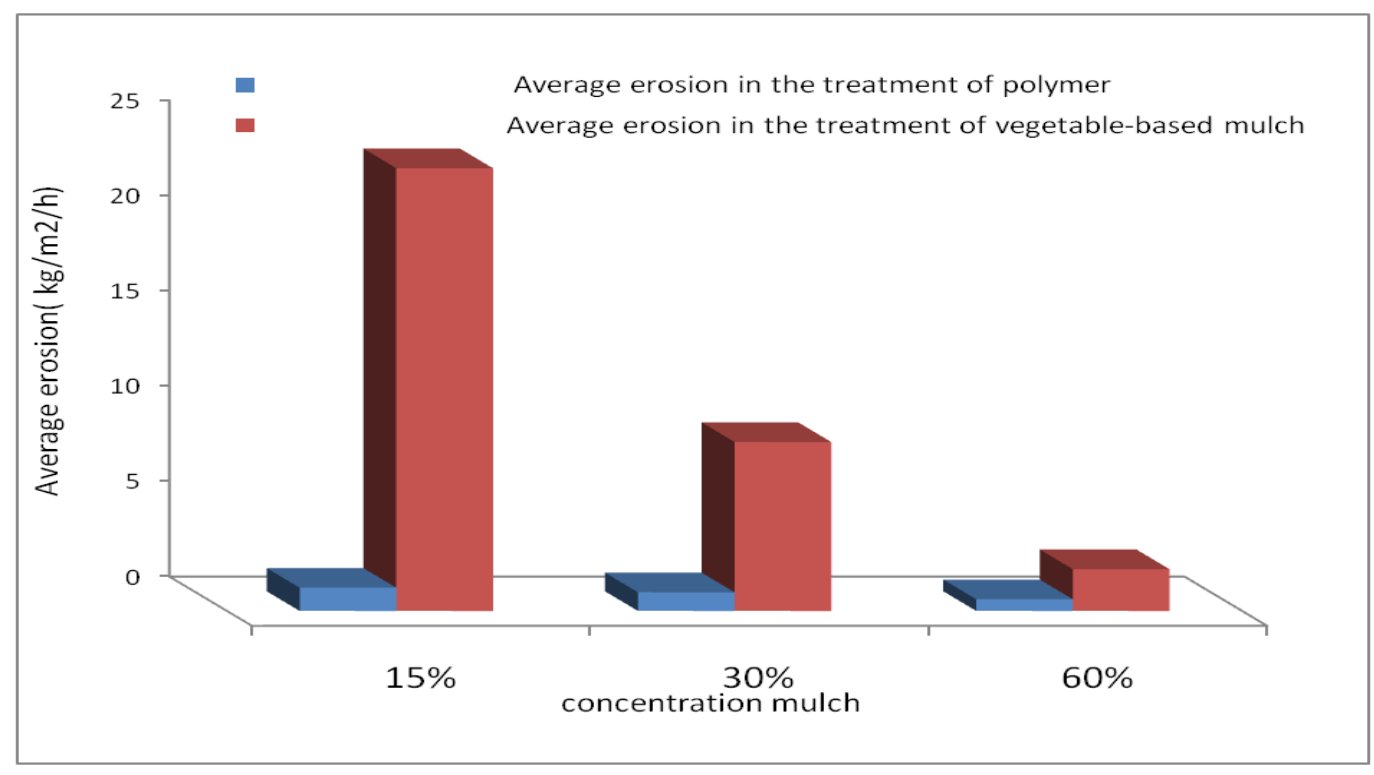

Figure 7 Average Borvayeh soil erosion in samples treated with polymer and vegetable-based mulch. 


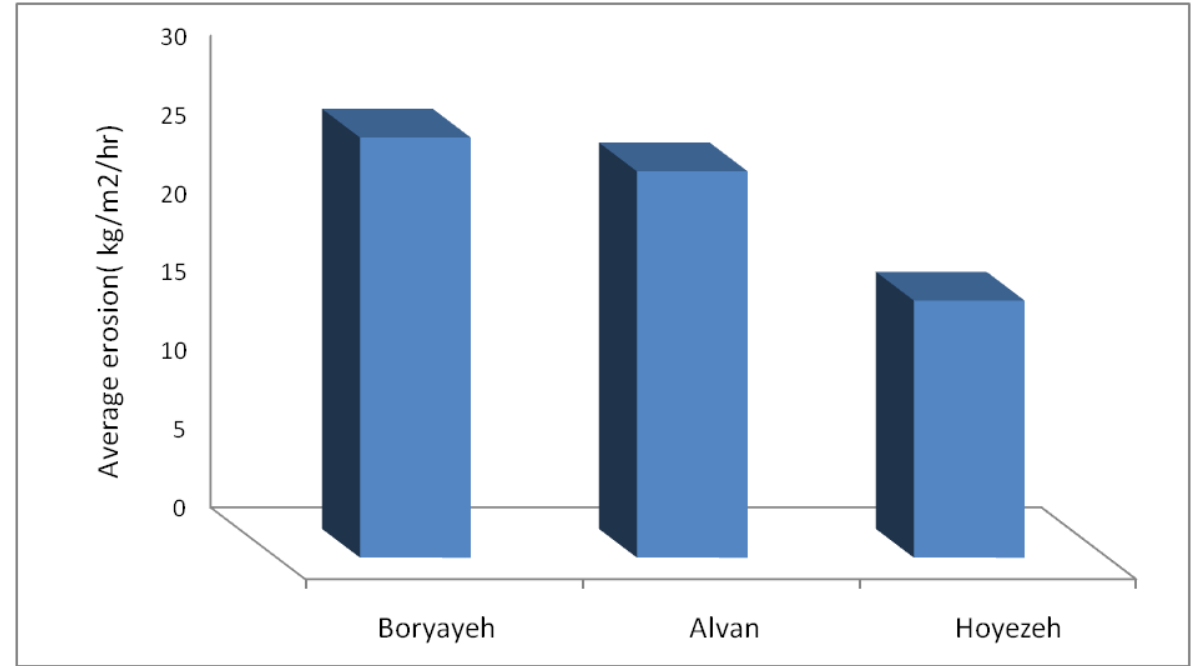

Figure 8 Average wind erosion in the selected locality Boryayeh, Alvan and Hoyezeh.

Polymer formed a perfectly smooth surface on the soil surface and this layer is free from any type of leaks and cracks, due to the high permeability in the soils it reached about $5 \mathrm{~mm}$ deep in to the sand and after drying it created the two layers. The top surface layer work as a solid sheet and has an integrated level and under this layer, attached soil particles are available without higher density.

Results of statistical analysis comparison between the types of soils showed that there is significant difference between wind erosion rate in the three soil samples. According to figure 8, the average wind erosion of Borvayeh, Alvan and Hoveyzeh samples at speed of 13 meters per second in simulators wind erosion was $26.73,24.58$ and 16.36 kilograms per square meter per hour, respectively. According the results of table 2, maximum soil loss in three sample sites at maximum speed (13 $\mathrm{m} / \mathrm{s}$ ) was reported from the samples collected from the Borvayeh localities and the soil of this locality have sandy texture with coarse grad and lacking organic matter. Duncan test showed that there is no significant difference between wind erosion rate at Alvan and Hoyeyzeh sampling site but the soil samples collected from Borvayeh localities are significantly different from these two, which can be different because of the size distribution of soil particles, organic matter and the type of ions in soils. Nohegar et al. (2011) in a study the use of polylattice polymer in Hormozgan province (Iran) and reported that used mulch had the ability to protect the sand against the wind (Nohegar et al., 2011).

\subsection{The effect of mulches on nutrients loss in soils}

Tables 4 and 5 showed the nutrients and organic matter losses in collected soil samples under wind erosion and impact of two types of mulch viz. polymer and vegetation-base mulch on the reduction of soil nutrients and organic matter loss reduction.

Table 4 Effect of vegetable-based mulch on the reduction of soil nutrients loss.

\begin{tabular}{|c|c|c|c|c|c|c|}
\hline \multirow[t]{2}{*}{ Type soil } & \multirow{2}{*}{$\begin{array}{c}\text { Concentration of vegetable- } \\
\text { based mulch }(\%)\end{array}$} & \multirow{2}{*}{$\begin{array}{c}\text { Average erosion } \\
\left(\mathrm{kg} / \mathrm{m}^{2} / \mathrm{h}\right)\end{array}$} & \multicolumn{4}{|c|}{ Nutrient loss $\left(\mathrm{g} / \mathrm{m}^{2} / \mathrm{h}\right)$} \\
\hline & & & Nitrogen & Phosphorus & Potassium & Organic matter \\
\hline \multirow[t]{4}{*}{ Borvayeh } & 0 & 26.73 & 0 & 2.67 & 38.22 & 0 \\
\hline & 15 & 23.25 & 0 & 2.32 & 33.17 & 0 \\
\hline & 30 & 8.87 & 0 & 0.887 & 12.67 & 0 \\
\hline & 60 & 2.19 & 0 & 0.217 & 3.10 & 0 \\
\hline \multirow[t]{4}{*}{ Alvan } & 0 & 24.58 & 1.229 & 111.3 & 38.34 & 49.16 \\
\hline & 15 & 0.98 & 0.049 & 4.44 & 1.52 & 1.96 \\
\hline & 30 & 0.49 & 0.0245 & 2.22 & 0.76 & 0.98 \\
\hline & 60 & 0.61 & 0.0305 & 2.76 & 0.95 & 1.22 \\
\hline \multirow[t]{4}{*}{ Hoveyzeh } & 0 & 16.36 & 0.818 & 1.637 & 20.45 & 32.73 \\
\hline & 15 & 0.73 & 0.0365 & 0.07 & 0.91 & 1.46 \\
\hline & 30 & 1.1 & 0.055 & 0.11 & 1.37 & 2.2 \\
\hline & 60 & 0.37 & 0.0185 & 0.04 & 0.46 & 0.74 \\
\hline
\end{tabular}


Table 5 Effect of vegetable-based mulch on the reduction of soil nutrients loss.

\begin{tabular}{|c|c|c|c|c|c|c|}
\hline \multirow[t]{2}{*}{ Type soil } & \multirow{2}{*}{$\begin{array}{c}\text { Polymer } \\
\text { concentration }(\%)\end{array}$} & \multirow{2}{*}{$\begin{array}{c}\text { Average erosion } \\
\left(\mathrm{kg} / \mathrm{m}^{2} / \mathrm{h}\right)\end{array}$} & \multicolumn{4}{|c|}{ Nutrient loss $\left(\mathrm{g} / \mathrm{m}^{2} / \mathrm{h}\right)$} \\
\hline & & & Nitrogen & Phosphorus & Potassium & Organic matter \\
\hline \multirow[t]{4}{*}{ Borvayeh } & 0 & 26.73 & 0 & 2.67 & 38.22 & 0 \\
\hline & 15 & 1.22 & 0 & 0.12 & 1.74 & 0 \\
\hline & 30 & 0.98 & 0 & 0.1 & 1.40 & 0 \\
\hline & 60 & 0.61 & 0 & 0.06 & 0.87 & 0 \\
\hline \multirow[t]{4}{*}{ Alvan } & 0 & 24.58 & 1.229 & 11.34 & 38.34 & 49.16 \\
\hline & 15 & 0.98 & 0.049 & 4.44 & 1.52 & 1.96 \\
\hline & 30 & 0.61 & 0.035 & 2.76 & 0.95 & 1.22 \\
\hline & 60 & 0.37 & 0.0185 & 1.68 & 0.57 & 0.74 \\
\hline \multirow[t]{4}{*}{ Hoveyzeh } & 0 & 16.365 & 0.818 & 1.637 & 20.45 & 32.7 \\
\hline & 15 & 1.83 & 0.0915 & 0.18 & 2.28 & 3.66 \\
\hline & 30 & 0.61 & 0.035 & 0.06 & 0.76 & 1.22 \\
\hline & 60 & 0.61 & 0.035 & 0.06 & 0.76 & 1.22 \\
\hline
\end{tabular}

Results presented in table 4 and 5 revealed that in Borvayeh sample average soil loss was reported $26.73 \mathrm{~kg} / \mathrm{m}^{2} / \mathrm{h}$ and due to wind total $2.67 \mathrm{~g} / \mathrm{m}^{2} / \mathrm{h}$ phosphorus and $38.22 \mathrm{~g} / \mathrm{m}^{2} / \mathrm{h}$ potassium reduction was reported. In this treatment, no reduction in the total nitrogen and organic loss was reported in this study. Further, average soil loss in Alvan sample was $24.58 \mathrm{~kg} / \mathrm{m}^{2} / \mathrm{h}$, while in case of nitrogen $1.229 \mathrm{~g} / \mathrm{m}^{2} / \mathrm{h}$, phosphorus $111.3 \mathrm{~g} / \mathrm{m}^{2} / \mathrm{h}$, potassium $38.34 \mathrm{~g} / \mathrm{m}^{2} / \mathrm{h}$ and organic matter $49.16 \mathrm{~g} / \mathrm{m}^{2} / \mathrm{h}$ reduction was reported due to wind erosion in simulators wind erosion device. On the other hand, in hoveyzeh sample soil loss was reported $16.37 \mathrm{~kg} / \mathrm{m}^{2} / \mathrm{h}$ due to wind erosion in simulators. While due to wind erosion device $0.818 \mathrm{~g} / \mathrm{m}^{2} / \mathrm{h}$ reduction in nitrogen, $1.637 \mathrm{~g} / \mathrm{m}^{2} / \mathrm{h}$ in phosphorus, $20.45 \mathrm{~g} / \mathrm{m}^{2} / \mathrm{h}$ in potassium and $32.73 \mathrm{~g} / \mathrm{m}^{2} / \mathrm{h}$ in organic matter were reported. Ha-Lin et al. (2006) reported nature of the geological formations in arid and semi-arid conditions and reported that elements such as carbon, nitrogen and phosphorus concentrations are low under these condition, on the other hand, the land exposed to wind erosion gradually lost nutrients, dropped percentage of fine particles in them and rises $\mathrm{PH}$.

As compare to other two localities, Alvan soil has higher amount of phosphorus that's why maximum loss of phosphorus was also reported from the sample collected from the Alvan $\left(111.3 \mathrm{~g} / \mathrm{m}^{2} / \mathrm{h}\right)$ while it was reported $2.67 \mathrm{~g} / \mathrm{m}^{2} / \mathrm{h}$ and $1.637 \mathrm{~g} / \mathrm{m}^{2} / \mathrm{h}$ for the Borvayeh and Hoveyzeh sample respectively. Similarly, maximum loss of nitrogen was reported from the sample collected from Alvan $\left(1.229 \mathrm{~g} / \mathrm{m}^{2} / \mathrm{h}\right)$ while this value was reported $0.818 \mathrm{~g} / \mathrm{m}^{2} / \mathrm{h}$ for the sample collected from Hoveyzeh. Nitrogen concentration in Borvayeh sample is zero this may be due to the lack of organic matter, sandy texture and high loss of nitrogen in arid and semi arid areas (Abassi et al., 2010a).With due attention to higher rates of soil loss at Alvan sample due to wind erosion in the wind erosion simulators, the amount of organic material lost in this sample $\left(49.16 \mathrm{gr} / \mathrm{m}^{2} / \mathrm{h}\right)$ is higher than the Hoveyzeh sample $\left(32.73 \mathrm{gr} / \mathrm{m}^{2} / \mathrm{h}\right)$.

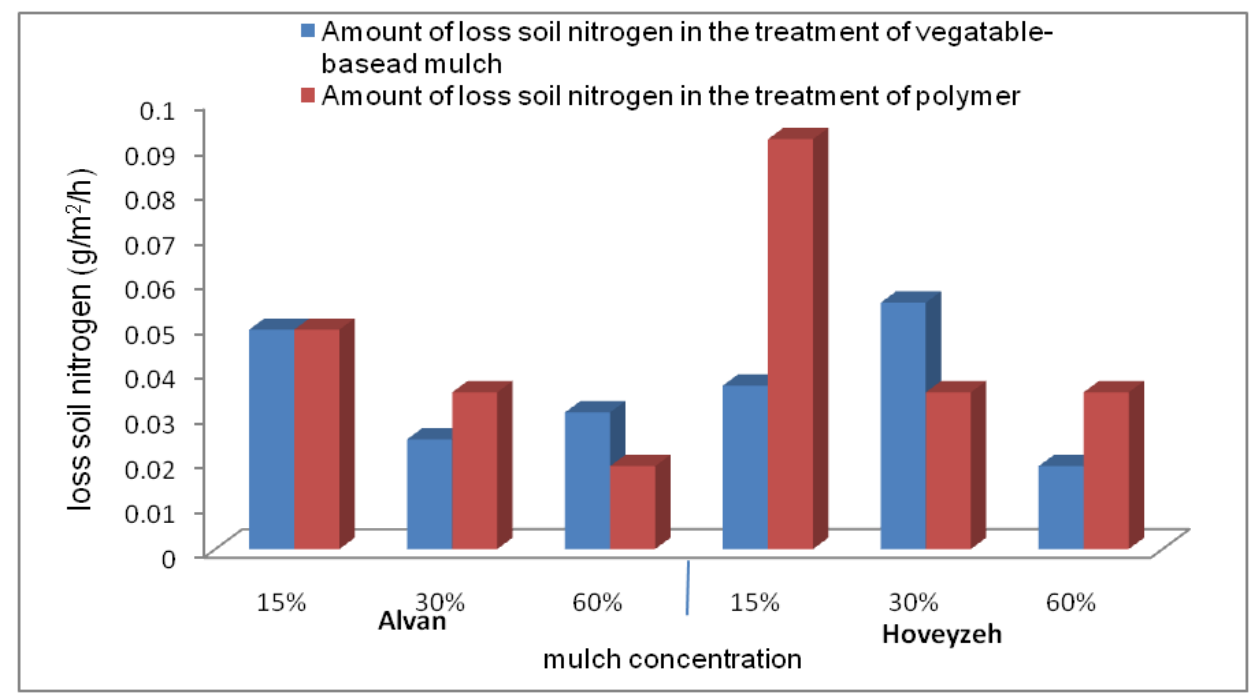

Figure 9 Average loss of soil nitrogen in Alvan and Hoveyzeh soil samples in two mulch treatment 
These results correspond with the finding of Lin et al. (2006) those who studied impact of wind erosion on the characteristics of sandy farmland in northern China. These researchers reported that wind erosion increased $6.2 \%$ sand particle, $3.7 \%$ $\mathrm{PH}, 2.2 \%$ temperature surface soil and decreased soil organic carbon, total nitrogen, total phosphorus, available nitrogen and soil moisture at rate $19.3 \%, 21.7 \%, 13.7 \%$ and $26.6 \%$ respectively (Lin et al 2006).

\subsubsection{The effect of mulches on nitrogen loss in soils}

Results of study suggested that use polymer in Alvan sample reduced the nitrogen loss from 1.229 to $0.049 ; 0.035$ and $0.0185 \mathrm{~g} / \mathrm{m}^{2} / \mathrm{h}$ on the concentrations of $15 \%, 30 \%$ and $60 \%$ respectively (table $4 \& 5$ ). Also similar type of reduction was reported in the Hoveyzeh sample $0.818 \mathrm{~g} / \mathrm{m}^{2} / \mathrm{h}$ to 0.0915 , 0.0305 and $0.0305 \mathrm{~g} / \mathrm{m}^{2} / \mathrm{h}$ at the same concentrations of 15,30 and $60 \%$ concentration respectively (Figure 9).

Compared to vegetable based mulching, polymer based mulching reduced nitrogen loss from $1.229 \mathrm{~g} / \mathrm{m}^{2} / \mathrm{h}$ to 0.049 , 0.0245 and $0.0305 \mathrm{~g} / \mathrm{m}^{2} / \mathrm{h}$ at the concentrations of 15,30 and $60 \%$ respectively. Similarly, use of polymer mulch also reduced nitrogen in Hoveyzeh sample from $0.818 \mathrm{~g} / \mathrm{m}^{2} / \mathrm{h}$ to $0.0365,0.055$ and $0.0185 \mathrm{~g} / \mathrm{m}^{2} / \mathrm{h}$, respectively at various concentrations of 15,30 and $60 \%$.Wang et al. (2006) studied dust storms and erosion in the lands of northern China and reported that severe dust storms can reduce the amount of carbon and nitrogen in soil up to $66 \%$ and $73 \%$ compared to control treatment in eroded lands.

\subsubsection{The effect of mulching on phosphorusloss in soils}

Use of vegetable-base mulching in Borvayeh sample were reduced phosphorus, in control total phosphorus was reported $2.673 \mathrm{~g} / \mathrm{m}^{2} / \mathrm{h}$ while in lowest dose treatment $(15 \%)$ it was reported $2.32 \mathrm{~g} / \mathrm{m}^{2} / \mathrm{h}$. With increasing the level of vegetable based mulching, reduction in the phosphorus was reported and minimum phosphorus loss $\left(0.217 \mathrm{~g} / \mathrm{m}^{2} / \mathrm{h}\right)$ was reported from the treatment containing $60 \%$ mulch concentration. In case of polymer mulching, maximum $0.12 \mathrm{~g} / \mathrm{m}^{2} / \mathrm{h}$ phosphorus losses was reported from the soil treated with $15 \%$ polymer concentration while the minimum phosphorus losses $(0.06$ $\mathrm{g} / \mathrm{m}^{2} / \mathrm{h}$ ) was reported from the soil treatment by $60 \%$ polymer concentration. Result of study revealed positive effects of polymer in reducing nutrient loss and it was superior to vegetable-base mulch (Figure 10).

Among the studied samples, Alvan sample treated with polymer had the highest phosphorus loss $111.3 \mathrm{~g} / \mathrm{m}^{2} / \mathrm{h}$ in control while the maximum reduction in phosphorus loss 4.44 $\mathrm{g} / \mathrm{m}^{2} / \mathrm{h}$ were recorded in the soil treated with $15 \%$ concentration of mulch and minimum $1.68 \mathrm{gr} / \mathrm{m}^{2} / \mathrm{h}$ in $60 \%$ concentration of polymer mulch.

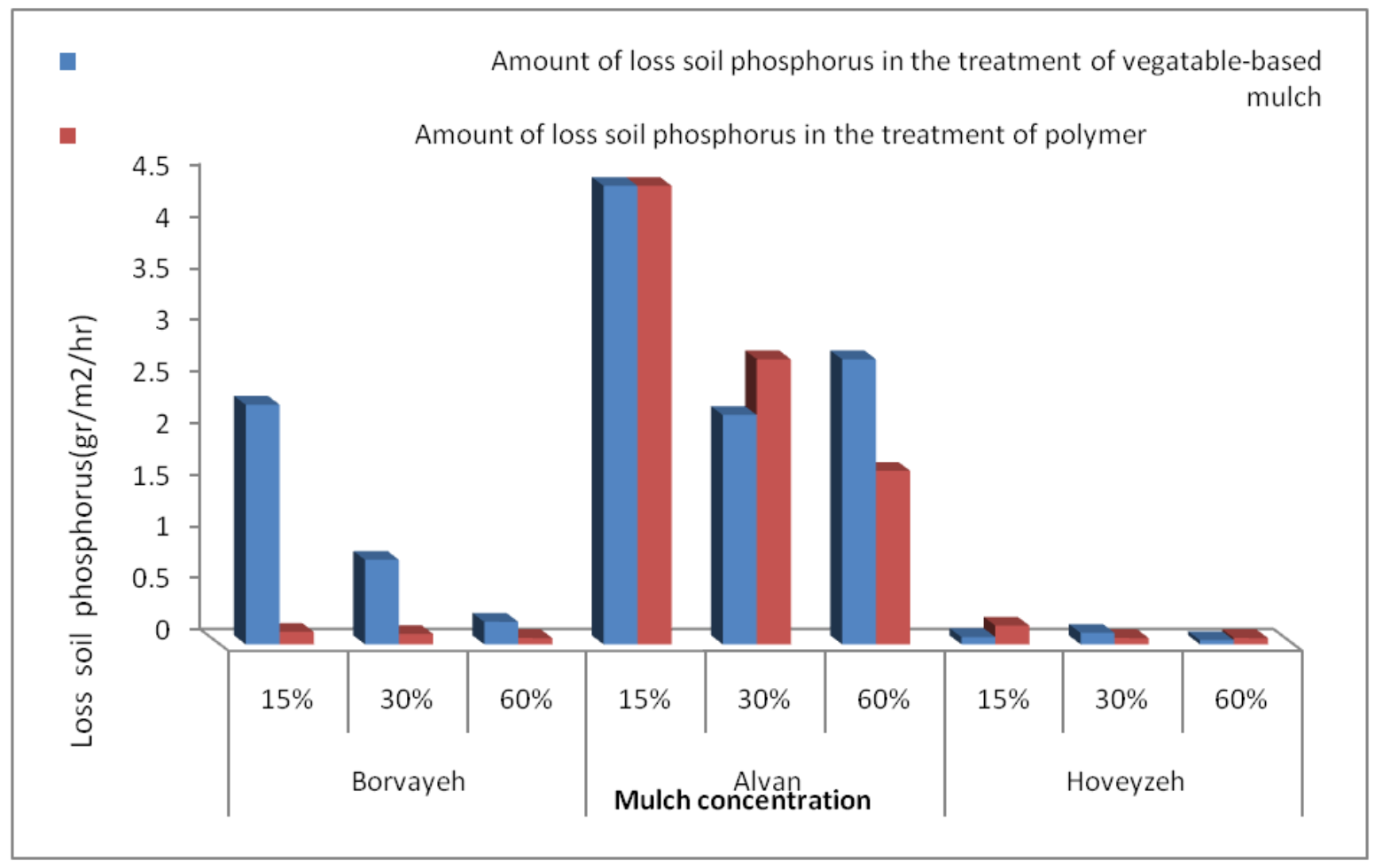

Figure 10 Compare the average loss of soil phosphorus in Alvan, Hoveyzeh and Borvayeh in treatment of two mulches 


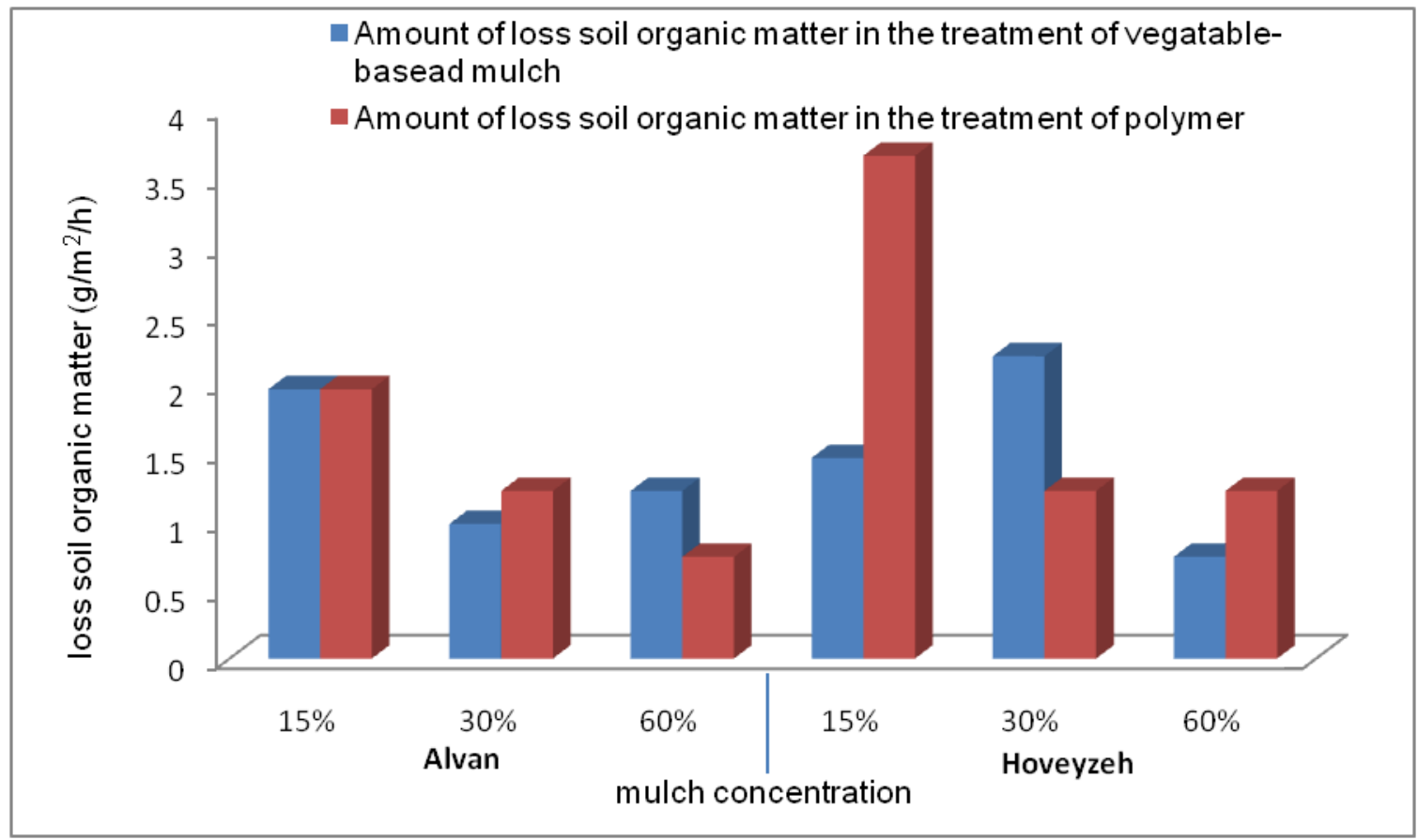

Figure 11 Compare the average loss of soil organic matter in Alvan and Hoveyzeh in treatment by two mulch.

\subsubsection{The effect of mulches on organic matter loss in soils}

Soil organic matter contented contains $94 \%$ Nitrogen and $25 \%$ to $50 \%$ phosphorus. Majority of the organic matter was reported in topsoil as the result of erosion become out of reach, studies have shown that organic materials eroded by wind or water, is 1.3-5 degree higher than the soil remains in place (Ashna Abad \& Ruhani, 2016).Organic matter in Borvayeh sample is zero which is one of the causes of higher average wind erosion and in effectiveness vegetable-base mulch (especially at low concentrations) was reported from this sample. Higher average wind erosion in Alvan sample caused during the test, more organic matter can be removed from Hoveyzeh sample.

According to figure 11, use of mulch in Alvan sample reduced organic matter loss $49.16 \mathrm{~g} / \mathrm{m}^{2} / \mathrm{h}$ in control to $0.74 \mathrm{~g} / \mathrm{m}^{2} / \mathrm{h}$ in $60 \%$ concentration polymer and $0.98 \mathrm{~g} / \mathrm{m}^{2} / \mathrm{h}$ in $30 \%$ concentration vegetable -base mulch. Also the loss of organic matter in Hoveyzeh samples treated with polymer were reduced organic matter loss of $32.73 \mathrm{~g} / \mathrm{m}^{2} / \mathrm{h}$ in control to minimum $1.22 \mathrm{~g} / \mathrm{m}^{2} / \mathrm{h}$ in $15 \%$ mulching while maximum reduction $0.74 \mathrm{~g} / \mathrm{m}^{2} / \mathrm{h}$ was reported in $60 \%$ concentration of vegetable-base mulch.

In general, adsorption of polymer to soil particles depends on polymer properties (molecular weight, type and charge density polymer), properties of the soil and its structure (soil type and texture, organic matter content and type of ions in soil). The nature of the interaction between the anionic polymer and the soil surface is not completely known, but hydrogen bonding and ligand exchange are two proposed mechanism for the interaction of these compounds with the soil (Lu et al., 2002).

\section{Conclusion}

In present study nutrient and soil organic matter loss and effect of two type mulch on reducing soil loss by wind erosion simulators were evaluated. Results of study revealed the effect of polymer and vegetable-base mulch on the reduction of nutrient loss. Mulching reduced $99 \%$ soil loss in the study area. But in Borvayeh soil mulching was not found effective in reducing soil loss at low concentrations. At $15 \%$ mulch concentration, wind erosion decreased only $13 \%$, this can be due to differences in the distribution of soil particle size, amount and type of organic matter and type of ions in soils. Loss of topsoil by wind erosion will follow the reducing in nutrients of soil and in future this may cause serious environmental and economic problems for the country. Use of mulch examined, with structural stability, were reduced $99.5 \%$ average nutrient loss in soil of studied area (Except in 15\% concentrations of vegetable mulch that nutrient loss was $13.2 \%)$.

Addition of polymer in soil creates linkage with soil particles and forms a long chain in the soil, which cause formation the interlocking between the various layers of the soil. This can reduces the rate of soil loss due to wind erosion. Stabilize soils disposed to wind erosion with mulch studied and planting native sapling and compatible with existing conditions are solution to resolving the problem of wind erosion and reduce dust phenomenon in the region. 


\section{Conflict of interest}

Authors would hereby like to declare that there is no conflict of interests that could possibly arise.

\section{References}

Abassi M, Feyznia S, Ahmadi H (2010a) Study of sand dunes origin by geochemical trades of eolian sediment in Niatak. Journal of Arid biome $1: 34-43$

Abbasi N, Movahedan M, KeramatiToroghi M (2010b) The effects of chemical polymer on physical and mechanical properties of soils. Agricultural Engineering Research Institute of Iran 89: 599. 64

Anasiru RH, Rayes ML, Budi Setiawan, Soemarno (2013) Economic Valuation of Soil Erosion on Cultivated Drylands in Langge Sub-watershed, Gorontalo, Indonesia. Journal of Natural Sciences Research $3: 40-48$

Ashna Abad M, Ruhani A (2016) Soil erosion; challenges, costs and benefits of conservation. Journal of Humans and the Environment $8: 47-58$

Behera B, Mohanty SK, Behura AK (2007) Effect of Mulches on Production Potential, Economics and Soil Fertility Status of Maize + Pigeonpea Intercropping under Rainfed Conditions of Eastern Ghats, Orissa. Indian Journal of Dryland Agricultural Research and Development $22: 37-40$

Bosede AJ (2010) Economic assessment of fertilizer use and integrated practices for environmental sustainability and agricultural productivity in Sudan savannah zone, Nigeria. African Journal of Agricultural Research $5: 338-343$.

Bremner JM (1982) Nitrogen -total. Agronomy Monograph, Methods of Soil Analysis. Part 2. Chemical and Microbiological Properties, 9: 1149-1178. doi:10.2134/agronmonogr9.2.c32.

Colazo JC, Buschiazzo D (2015) The impact of agriculture on soil texture due to wind erosion. Land Degradation \& Development 26 : 62-70. DOI: 10.1002/ldr.2297.

Ghozikali MG, Mosaferi M, Safari GH, Jaafari J (2015) Effect of exposure to $\mathrm{O} 3, \mathrm{NO} 2$, and $\mathrm{SO} 2$ on chronic obstructive pulmonary disease hospitalizations in Tabriz, Iran. Environmental Science and Pollution Research International 22 : 2817-2823. DOI: 10.1007/s11356-014-3512-5.

Gravandi S,Zalagh A, Goodarzi G, Mohamadi M, Babaee A, Yari A, Nourzadeh HM (2016) Exposure To Particulate Matter Of Less Than 10 Microns And Its Effect On Respiratory And Cardiovascular Diseases In Isfahan, Iran in 2013. Health System Research $11: 725-730$.
Ha-Lin Z, Xiao-Yong Y, Rui-Lian Z, Xue-Yong Z, Tong-Hui $Z$, Sam D (2006) Wind erosion and sand accumulation effects on soil properties in Horqin Sandy Farmland, Inner Mongolia. $\begin{array}{llll}\text { CATENA } & 65 & \text { : } & 71-79 .\end{array}$ http://dx.doi.org/10.1016/j.catena.2005.10.001.

Han Z, Wang T, Dong Z, Hu Y, Yao Z (2007) Chemical stabilization of mobile dunefields along a highway in the Taklimakan Desert of China. Journal of Arid Environments 68 : 260-270. DOI: http://dx.doi.org/10.1016/j.jaridenv.2006.05.007.

Li J, Okin GS, Alvarez L, Epstein H (2007) Quantitative effects of vegetation cover on wind erosion and soil nutrient loss in a desert grassland of southern New Mexico, USA. Biogeochemistry 85 : 317-332. DOI: 10.1007/s10533-0079142-y.

KohneShahri L, Sadeghi H (2005) The estimated economic impacts of soil erosion in Iran. Journal of Economic Studies 15: $88-100$

Lu JH, Wu L, Letey J (2002) Effects of Soil and Water Properties on Anionic Polyacrylamide Sorption. Soil Science of American Journal 66: 578-584. doi:10.2136/sssaj2002.5780.

Khan, MS (2014) Reviewing the performance of mulch F2SR231 polymer to stabilize sand dunes. In: The Third National Conference on Wind Erosion and Dust Storms, Yazd, Iran

National Project Management dust (2010) EPA Tehran. National Secretariat of dust.

Nohegar A, Abbaszadeh F, Akbarian M, HatamiGourband H (2011) Reviews performance polymer polylattice in soil protection against wind erosion. Research, Environmental Degradation 3:5-15.

Nourzadehhadad M, Bahrami A (2016) Study of mineralogy and sensitive sources of dust to the soil surface moisture, Case Western lands Khuzestan province.mjlh Geographical Space (In press).

Nourzadeh M, Bahrami HA, Goossens D, Fryrear D (2013) Determining soil erosion and threshold friction velocity at different soil moisture conditions using a portable wind tunnel. Zeitschrift Für Geomorphologie 57 : 97-109. DOI: 10.1127/0372-8854/2012/0089.

Olsen SR, Sommers LE (1982) Phosphorus. In: Page AL, Miller RH (Eds). Methods of Soil Analysis. Part 2. 2nd ed. Agronomy Monograph 9, ASA and SSSA, Madison, WI, pp. 403-430.

Thomas GW (1982) Exchangeable cations. In: Page AL, Miller RH (Eds). Methods of Soil Analysis. Part 2. 2nd ed. Agronomy Monograph 9, ASA and SSSA, Madison, WI, Pp. 154-157. 
Walkley A, Black IA (1934) An examination of Degtjareff method for determining soil organic matter and a proposed modification of the chromic acid titration method. Soil Science 37:29-37.

Wang X, Oenema O, Hoogmoed WB, Perdoku D, Cia D (2006) Dust storm erosion and its impact on soil carbon and nitrogen losses in northern China. CATENA 66 : 221-227. DOI: http://dx.doi.org/10.1016/j.catena.2006.02.006.

Zalaghi E ( 2010) Survey of health effects of air pollution Ahvaz, Bushehr and Kermanshah with use of AIRQ model. M. Sc. Thesis submitted to the Islamic Azad University, Science and Research Branch, Ahvaz,Iran.
Burri K, Gromke CH, Lehning M, Graf F ( 2011 ) Aeolian sediment transport over vegetation canopies : a wind tunnel study with live plant . Aeolian Research 3 : 205-213

Lopez MV (1998) Wind erosion in agricultural soil : an example of limited supply of particles available for erosion. CATENA 33 :17-28. DOI: http://dx.doi.org/10.1016/S03418162(98)00064-2.

Mahmoud abadi M, Dehghani F, Azim zadeh H (2011) Effect of particle size distribution on the intensity of wind erosion. Soil Management and Sustainable Production 1 : 98-81. 